\title{
Agroecological foundations of alternative agriculture in California
}

\author{
Miguel A. Altieri \\ Division of Biological Control, University of California - Berkeley, 1050 San Pablo Avenue, Albuny, \\ CA 94706, USA
}

(Accepted 9 July 1991)

\begin{abstract}
Altieri, M.A., 1992. Agroecological foundations of alternative agriculture in California. Agric. Ecosystems Environ. 39: 23-53.

Most agricultural regions of California enjoy long growing seasons, fertile soils and irrigation, all conditions that favor a highly diversified cropping. In addition, the wide variety of vegetables, field and tree crops determine a high diversity and flexibility of agricultural enterprises. Despite these factors, Californian agrcecosystems are dominated by monocultural cropping systems. Although productive, these systems lack the ecological features to ensure efficient nutrient cycling, water and soil conservation, and biotic regulation. Productivity is subsidized with chemical inputs such as pesticides and fertilizers, some of which cause undesirable environmental and public health hazards. Large-scale monocultures are also highly susceptible to wind erosion and are dependent on ground water for irrigation, leading in some areas to a considerable 'overdraft'. In other regions, poor field drainage and rising water tables are Ir.ading to unacceptable soil salinity levels. In stimmary, Californian agriculture is very productive, but the environmental cost of such productivity is threatening the sustainability of agriculture.

The search for self-sustaining, low-input, diversified and energy-efficient agricultural systems is now a major concern of researchers, farmers, policy makers and the public in California. The long tradition in biological pest control in California, as well as the experience of a number of organic farmers who developed low-input systems through 'trial and error', provide the building blocks for the search for a more sustainable agriculture.

A key strategy in sustainable agriculture is to restore the agricultural diversity of the agricultural landscape. Diversity can be enhanced in time through crop rotations and sequences, and in space in the form of cover crops, intercropping, agroforestry crop/livestock mixtures, etc. Vegetation diversification not only results in pest regulation through restoration of natural controls, but also produces optimal nutrient recycling, energy conservation and less dependence on cultural inputs. In California, although this new approach to agriculture is actively researched, realistically it will work only if it is economically sensible and can be carried out within the constraints of a fairly normal agricultural system. Therefore, adoption of recommended diversification designs will proceed as these reduce costs and increase the efficiency and viability of farmers.
\end{abstract}

\section{INTRODUCTION}

The link between agriculture and ecology is as old as agriculture itself. Throughout the world, ecological knowledge has played a crucial role in the

Correspondence to: M.A. Altieri, Division of Biological Control, University of California Berkeley, 1050 San Pablo Avenue, Albany, CA 94706, USA.

(C) 1992 Elsevier Science Publishers B.V. All rights reserved 0167-8809/92/ $\$ 05.00$ 
evolution and practice of farming. Until about four decades ago, in California, crop yields depended on internal resources, recycling of organic matter, built-in biological pest control mechanisms and rainfall patterns. Inputs of nitrogen were gained by rotating major field crops with legumes. In turn, rotations suppressed insects, weeds and diseases by effectively breaking the life cycles of these pests. Today, many of these practices have been abandoned by farmers with the advent of chemicals and mechanized technology (Scheuring, 1983).

Modern agriculture's energy-intensive production is supported by the availability of fossil fuels, electricity and manufactured inputs. Given the historic rise in the costs of labor and management relative to those of purchased inputs, the evolution of energy-intensive agriculture has been a logical outcome of market forces. This agricultural transformation was facilitated by institutional modifications which complemented market trends and made the adoption of modern agriculture even more attractive (Douglass, 1984).

Machinery, fertilizers, fuels, pesticides and irrigation inputs all effectively increase crop production, but do so with a growing array of ecological and social problems. Some of the attractiveness of modern technologies to the individual farmers stems from the fact that most of the resulting social and environmental costs of technological application are borne by the agricultural sector collectively or by society at large (Liebman, 1983).

As agricultural modernization progresses, the ecology-farming linkage is often broken as ecological principles are ignored or overridden. Today, in California, these breakdowns manifest themselves as recurrent pest outbreaks in many cropping systems and also in the form of salinization, soil erosion, pollution of water systems, etc. Closure of 42000 acres of prime farm land in Kesterson owing to high selenium concentrations in the irrigation water, removal of watermelons and apples from the market because of toxic pesticide residues and alar, respectively, and increasing pollution of ground water with pesticides and fertilizers are but a few symptoms. Record farm foreclosures, rising farm debt, falling commodity prices and enhanced government subsidy payments to prop up farm prices are also symptomatic of the current farm crisis.

Part of the breakdown is derived from agricultural policies that emphasize higher yields, but ignore environmental and socioeconomic concerns. The effect of this trend has been the promotion of uniform production technologies that do not always fit the ecological, social and economic circumstances of the wide variety of farms in the state. Clearly, farmers in California with small diversified farms, which combine intensive production of vegetables, orchards or vineyards and, in a few cases livestock, have many different problems and needs than large cotton farmers in the San Joaquin Valley. If this is not recognized, fundamental incompatibilities between agroecological and socioeconomic processes and new technology will continue to arise. As farm- 
ers tie their financial troubles to the increased capitalization and specialization in modern agriculture, they are becoming more receptive to alternative low-cost, low-input agricultural systems. An increasing number of small farmers today rarely blindly endorse modern technologies normally considered benign or size-neutral. The experiences of a number of organic farmers who developed low-input production systems virtually through 'trial and error' and the long tradition of applied biological pest control, pioneered by the University of California, provide the 'building blocks' for the search of a more sustainable agriculture in California.

\section{THE EXPANSION OF MONOCULTURES}

Before the advent of modern plant breeding, agricultural yields were modest, but relatively stable. Agricultural production was safeguarded by growing more than one crop or variety in space and time in a field as insurance against outbreaks of diseases, pests or severe weather. Today, however, monocultures have increased dramatically in California, mainly through the geographical expansion of land devoted to single crops and year-to-year prosuction of the same crop species on the same land. Available data indicate that the amount of crop diversity per unit of arable land has decreased and that croplands have shown a tendency toward concentration. There are political and economic forces influencing the trend to devote large areas to monoculture. Farms today are fewer, larger, more specialized and more capital intensive. Economies of scale, stimulated in part by public research on such scale-biased technology as large equipment and capital-intensive chemical inputs, have permitted farmers to reduce unit production costs by increasing farm size (United States Department of Agriculture (USDA), 1973).

This transformation has led to the image of California's agriculture as a modern miracle of food production. In fact, today California is the leading agricultural state and ranks first in the production of 49 different crops and livestock products. According to 1980 figures, milk ( $\$ 1.78$ billion) is number one among the state's 250 different agricultural products, followed by cattle and calves ( $\$ 1.44$ billion), cotton ( $\$ 1.39$ billion) and grapes ( $\$ 1.22$ billion). Nearly a quarter of the state's total farm production is now being sold abroad. Export crop receipts are led by cotton (over $\$ 1$ billion, representing nearly $53 \%$ of total US cotton exports), almonds ( $\$ 339$ million), wheat ( $\$ 248$ million) and rice ( $\$ 259$ million).

Viewed in terms of relative productivity, California's $33.4 \times 10^{6}$ acres of agricultural land, although accounting for only $3 \%$ of the nation's total farmland, produced nearly $10 \%$ of the country's agricultural cash receipts for 1980 . California has also experienced an extraordinary growth in new land brought under cultivation, resulting from largely the expansion of irrigation systems in the San Joaquin Valley and the southern part of the state. Over the last $\mathbf{4 0}$ 
years, acres of irrigated land have increased from $4.3 \times 10^{6}$ to $9.4 \times 10^{6}$. On the other hand, the rate of crop land lost to urb anization proceeds at about 64000 acres year $^{-1}$ (Mazmanian, 1982).

At the regional level, increases in monoculture farming mean that the whole agricultural support infrastructure (i.e. extension, suppliers, storage, transport, markets, etc.) has become more specialized.

From an ecological perspective, the consequences of this crop specialization are many-fold.

(a) Most of California's large-scale agricultural systems exhibit a poorly structured assemblage of farm components, with almost no linkages or complementary relationships between crop enterprises and among soils, crops and animals.

(b) Cycles of nutrients, energy, water and wastes have become more open, rather than closed as in a natural ecosystem.

(c) Part of the instability and susceptibility to pests of agroecosystems can be linked to the adoption of vast crop monocultures, which have concentrated resources for specialist crop herbivores and have increased the areas available for immigration of pests. This simplification has also reduced environmental opportunities for natural enemies. Consequently, pest outbreaks often occur when large numbers of immigrant pests, inhibited populations of beneficial insects, favorable weather and vulnerable crop stages happen simultaneously.

(d) It is estimated that, in California, the total amount of crop residue and manure produced averages $12.5 \times 10^{6}$ and $4.3 \times 10^{6}$ tons, respectively. Despite this substantial amount of biomass, it is becoming increasingly difficult to recycle nutrients, even within agricultural systems. Animal wastes cannot economically be returned to the land in a nutrient-recycling process because production systems are geographically remote from other systems which would complete the cycle. In many areas, agricultural waste has become a liability rather than a resource. Recycling of nutrients from urban centers back to the fields is similarly difficult.

(e) As specific crops are expanded beyond their 'natural' ranges or favorable regions to areas of high pest potential, or with limited water, or lowfertility soils, intensified chemical controls are required to overcome such limiting factors. The assumption is that the human intervention and level of energy inputs that allow these expansions can be sustained indefinitely.

\section{YIELD INSTABILITY IN CALIFORNIAN AGROECOSYSTEMS}

Although yields per crop/unit area have increased in California, when examined over long time spans yields usually exhibit low stability trends, as exemplified by cotton yields in a 70 year period (Fig. 1(a)). An important factor contributing to the observed yield instability in modern agriculture is that yields depend on purchased inputs. If fertilizers, herbicides and pesti- 

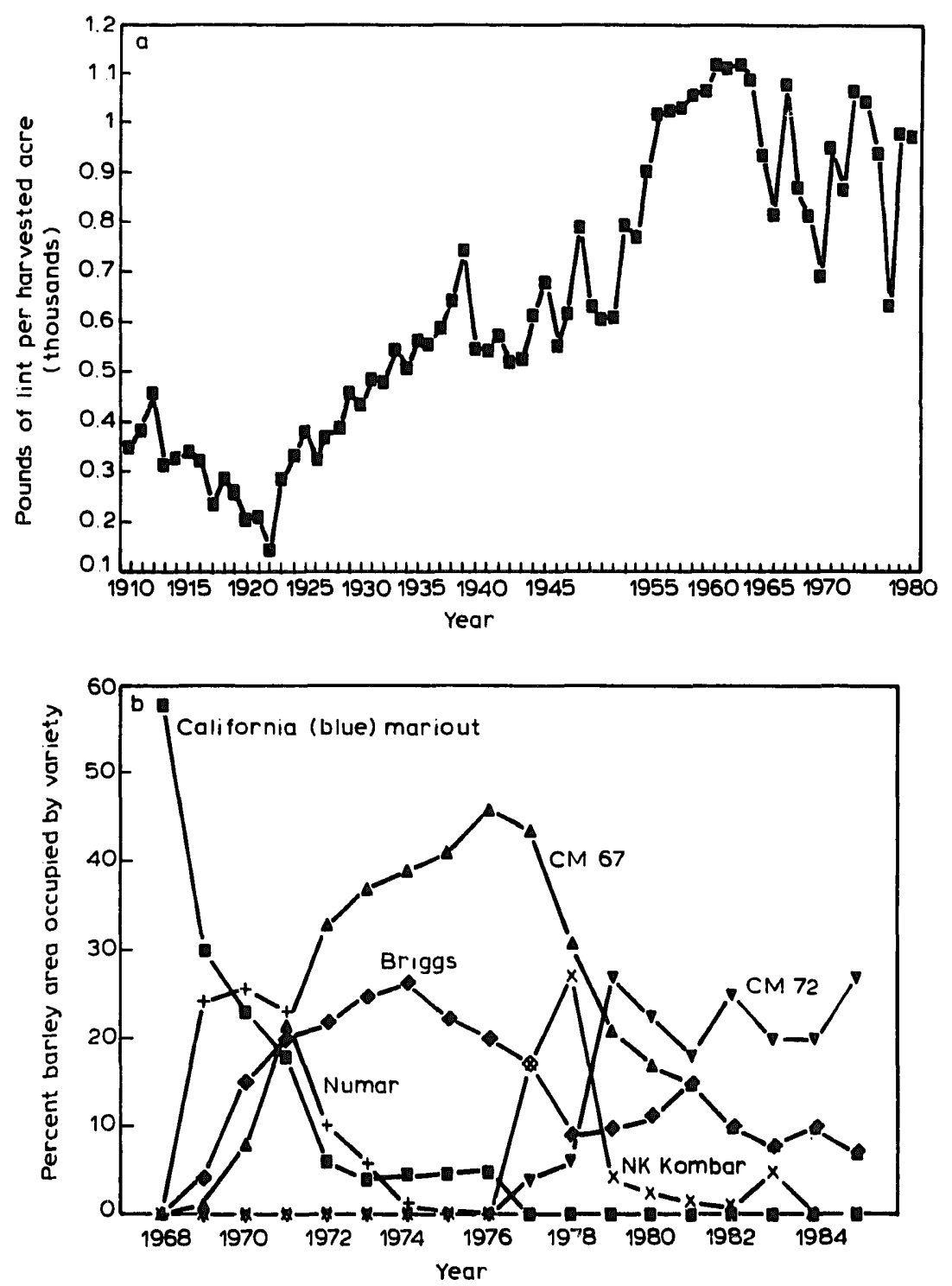

Fig. 1. (a) Cotton yields in California from 1910 to 1980 (California Crop and Livestock Reporting Service). (b) Lifespan of selected barley varieties in California from 1968 to 1985 (California Crop and Livestock Reporting Service).

cides, for example, are not applied at the correct time or in sufficient quantities, yields can suffer; yet farmers are sometimes constrained from using agrichemicals correctly because of sudden price increases, supply shortages, and changes in subsidy and credit policies. Modern agriculture thus requires unprecedented management precision to avert serious production shortfalls (Plucknett and Smith, 1986).

Although Californian farmers have commonly adopted and then eventually 
abandoned crop varieties for numerous ecological and cultural reasons, the rate of variety substitution has recently accelerated to unprecedented levels. Commercial farmers witness a constant march of new crop varieties. Varietal replacement is typically faster for annuals than for perennial or tuber crops. A cultivar with improved disease or insect resistance makes a debut, performs well for a few years and is then succeeded by another variety when yields begin to slip, productivity is threatened, or a more promising cultivar becomes available. A variety's trajectory is characterized by a take-cff phase when it is adopted by farmers, a middle stage when the planted area stabilizes and finally a retraction of its acreage. Stability in modern agriculture hinges on a continuous supply of new cultivars rather than a patchwork quilt of many different varieties planted on the same farm.

The lifespans of cultivars vary according to the crop and region. In the case of wheat and barley in California, for example, some cultivars remain productive for over a decade, whereas farmers drop others after only a few seasons (Fig. 1(b)). In the USA, the average lifetime of a cultivar of cotton, soybean, wheat, maize, oats or sorghum ranges from 5 to 9 years.

\section{SUSTAINABLE AGRICULTURE}

Sustainable agriculture refers to a mode of farming that attempts to provide long-term sustained yields through the use of ecologically sound management technologies. This requires that agriculture be regarded as an ecosystem (hence, the term agroecosystem) and, as such. farming and research are not concerned with high yields of a particular commodity, but rather with the optimization of the system as a whole. It also requires us to look beyond production economics and to consider the vital issue of ecological statility and sustainability.

The performance of agroecosystems can be described by four properties: sustainability, equity, stability and productivity (Conway, 1985).

Sustainability relates to the ability of an agroecosystem to maintain production through time, in the face of long-term ecological constraints and socioeconomic pressures. It also relates to the resiliency of an agroecosystem, i.e. its ability to recover after being subjected to stress. Productivity in agricultural systems cannot be increased indefinitely. A ceiling is placed on potential productivity by the physiological limits of crops, the "carrying capacity' of the habitat and the external costs incurred during efforts to increase production. An equilibrium can be reached between sustained yields and environmental and management factors. It will vary with different crops, geographical areas and energy inputs and, therefore, will be highly 'site specific'.

Equity is a measure of how evenly the products of the agroecosystem (income, produce, etc.) are distributed among the local producers and consumers. It includes issues such as adequate income, good nutrition and a sat- 
isfactory amount of leisure, but many aspects of equity are not easily definable or measurable in scientific terms.

Stability is the constancy of production under a given set of environmental, economic and management conditions. Some ecological pressures are rigid constraints in the sense that the farmer is virtually unable to modify them. In other cases, the farmer can improve the biological stability of the system by choosing more suitable crops or developing methods of cultivation that improve yields. The land can be irrigated, mulched, manured or rotated, or crops can be grown in mixtures to improve the resilience of the system.

Productivity is a measure of the rate and the amount of production per unit of land or input. In ecological terms, production refers to the amount of yields or end product, and productivity is the process for achieving that end product. When the above indicators of performance are used to evaluate the viability of California's agroecosystems, it becomes apparent that although, historically, the introduction of new technology has greatly increased short-term productivity, it has also in the long-term lowered the stability, sustainability and equity of the total agricultural system (Conway, 1985). When compared with traditional farming systems in developing countries, California's systems appear ecologically fragile and unsound. In developing countries, small farmers place a higher value on reducing risk than on maximizing production. Small farmers are usually interested in optimizing the productivity of scarce farm resources, not necessarily in increasing land or labor productivity. Also, small farmers choose a particular production technology based on decisions made for the entire farming system and not only for a particular crop (Harwood, 1979).

\section{REQUIREMENTS OF A SUSTAINABLE AGRICULTURAL SYSTEM}

The basic tenets of a sustainable agroecosystem are the conservation of renewable resources, adaptation of the crop to the environment and maintenance of a moderate but sustainable level of productivity. To emphasize longterm ecological sustainability rather than short-term productivity, the production system must: (1) reduce energy and resource use, and regulate the overall energy input so that the output:input ratio is high; (2) reduce nutrient losses by effectively containing leaching, run-off and erosion, and improve nutrient recycling through the promotion of legumes, organic manures and compost, and other effective recycling mechanisms; (3) encourage local production of food items adapted to the natural and socioeconomic setting; (4) sustain a desired net output by preserving the natural resource, i.e. by minimizing soil degradation; (5) reduce costs and increase the efficiency and economic viability of small and medium-sized farms, thereby promoting a diverse, potentially resilient agricultural system.

As shown in Fig. 2, from a management viewpoint, the basic components 


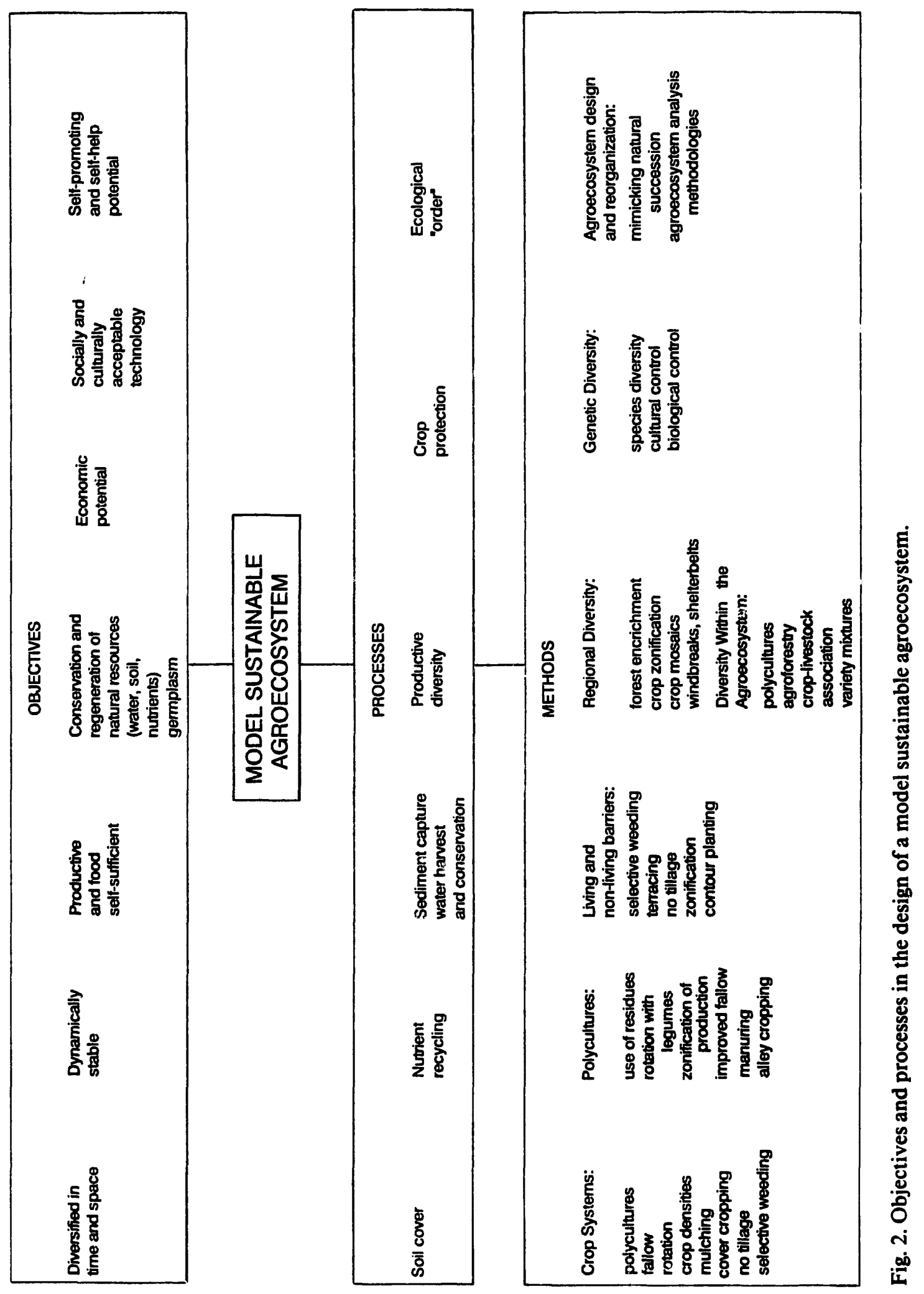


of a sustainable agroecosystem include: (1) vegetative cover as an effective soil- and water-conserving measure, met through the use of no-till practices, mulch farming, use of cover crops, etc.; (2) regular supply of organic matter through the regular addition of organic matter (manure, compost) and promotion of soil biotic activity; (3) nutrient recycling mechanisms through the use of crop rotations, crop/livestock mixed systems, agroforestry and intercropping systems based on legumes, etc.; (4) pest regulation assured through enhanced activity of biological control agents, achieved by introducing and/ or conserving natural enemies.

\section{RESTORING DIVERSITY IN AGRICULTURAL SYSTEMS}

Most agricultural provinces of California enjoy long growing seasons, fertile soils and irrigation which favor a highly diversified, but regionalized cropping. The wide variety of vegetables, field and tree crops determine a high diversity and flexibility of agricultural enterprises at the state level. Crop species diversity is, however, remarkably low at the local and farm level. California has many types of agricultural systems, determined by local variations in climate, soil, economic relations, social structure and history. Clearly, these systems are always changing in size, land tenure assignments and technological intensity, forced by population shifts, resource availability, environmen-

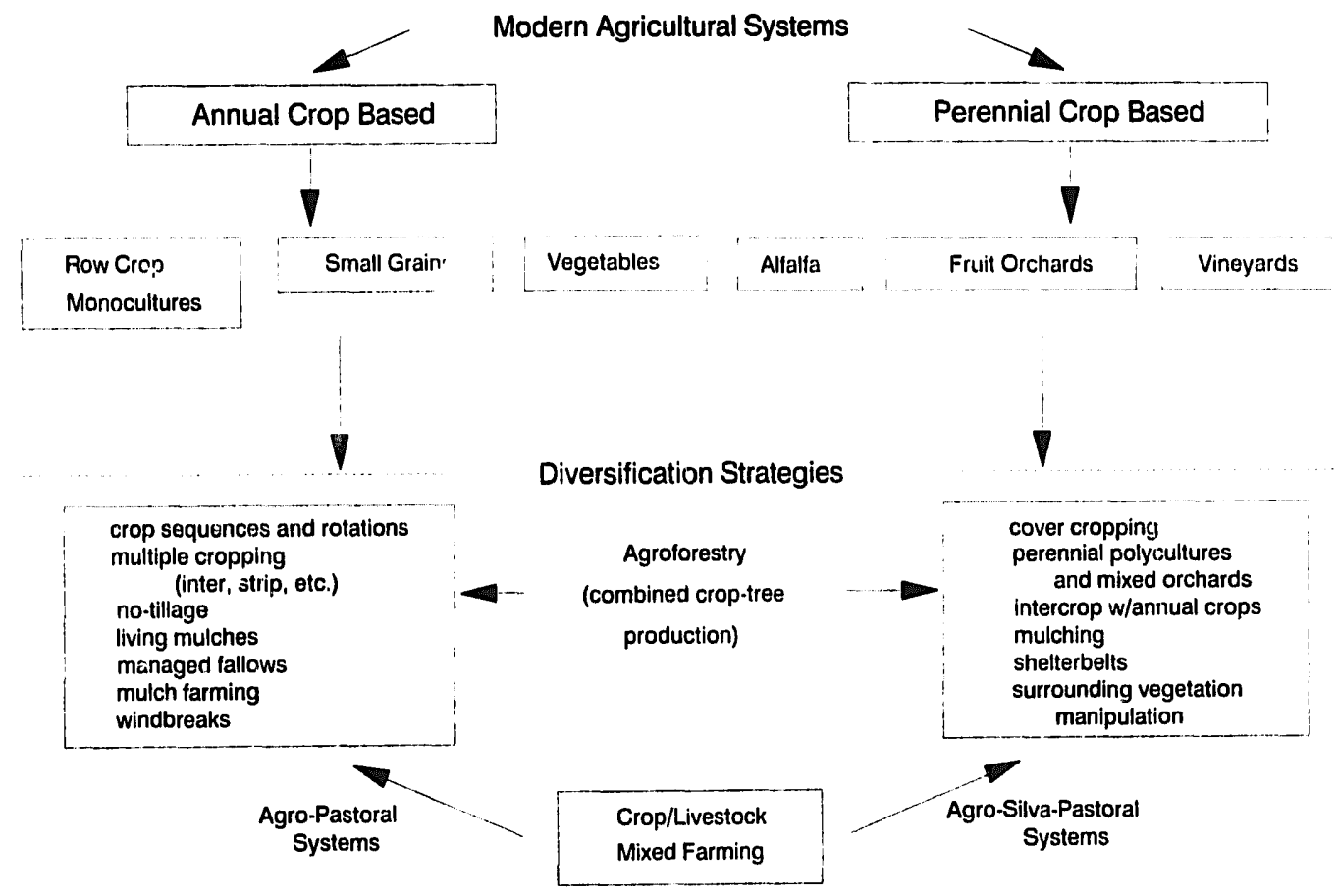

Fig. 3. Diversification options for annual or perennial crop based cropping systems in California. 


\section{TABLE 1}

Examples of alternative cropping systems tested in California that emphasize diversification strate-

\begin{tabular}{|c|c|c|c|}
\hline $\begin{array}{l}\text { Diversification } \\
\text { strategy }\end{array}$ & Cropping system & Main effects & Reference \\
\hline \multirow[t]{5}{*}{ Crop rotation } & $\begin{array}{l}\text { Rhodegrass, } \\
\text { Timothy grass- sour } \\
\text { orange seedlings }\end{array}$ & $\begin{array}{l}\text { Increased seedling } \\
\text { growth }\end{array}$ & Martin and Ervin, 1954 \\
\hline & $\begin{array}{l}\text { Sugarbeets - non- } \\
\text { host crops } \\
\text { Vetch-rice }\end{array}$ & $\begin{array}{l}\text { Reduced incidence } \\
\text { of cyst nematode } \\
\text { Increased } \mathrm{N} \text { and } \\
\text { enhanced rice yield }\end{array}$ & $\begin{array}{l}\text { Roberts and Thumason, } \\
1981 \\
\text { Williams and Dawson, } \\
1980\end{array}$ \\
\hline & $\begin{array}{l}\text { Barley-onions or } \\
\text { potatoes }\end{array}$ & $\begin{array}{l}\text { Decreased root-knot } \\
\text { nematode, enhanced } \\
\text { barley yield }\end{array}$ & Allen et al., 1970 \\
\hline & $\begin{array}{l}\text { Cotton-paddy rice or } \\
\text { perennial rye grass }\end{array}$ & $\begin{array}{l}\text { Reduction in } \\
\text { Verticillium wilt }\end{array}$ & Butterfield et al., 1978 \\
\hline & $\begin{array}{l}\text { Cotton-barley, corn } \\
\text { or sorghum }\end{array}$ & $\begin{array}{l}\text { Reduction in } \\
\text { Verticillium wilt }\end{array}$ & Wilhelm et al., 1966 \\
\hline \multirow[t]{5}{*}{ Cover cropping } & $\begin{array}{l}\text { Alfalfa and hubam } \\
\text { clover in pears }\end{array}$ & $\begin{array}{l}\text { Improved water } \\
\text { infiltration in } \\
\text { orchard soil }\end{array}$ & Werenfels et al., 1963 \\
\hline & $\begin{array}{l}\text { Vetch and fava beans } \\
\text { in apple orchards }\end{array}$ & $\begin{array}{l}\text { Decreased incidence } \\
\text { of codling moth, rosy } \\
\text { apple aphids and } \\
\text { leafhoppers; } \\
\text { enhanced apple } \\
\text { yields }\end{array}$ & $\begin{array}{l}\text { Altieri and Schmidt, } \\
\text { 1986a }\end{array}$ \\
\hline & $\begin{array}{l}\text { Oleander under } \\
\text { citrus }\end{array}$ & $\begin{array}{l}\text { Insectary for the } \\
\text { produrtion of the } \\
\text { black scale parasite } \\
\text { Metaphycus helvolus }\end{array}$ & Flanders, 1949 \\
\hline & $\begin{array}{l}\text { Several cover crops } \\
\text { in orange }\end{array}$ & $\begin{array}{l}\text { Long-term increase } \\
\text { in orange yields }\end{array}$ & Parker and Jones, 1951 \\
\hline & $\begin{array}{l}\text { Ground cover of } \\
\text { Johnson or sudan } \\
\text { grass in vineyards }\end{array}$ & $\begin{array}{l}\text { Enhanced predation } \\
\text { of Willamette mite }\end{array}$ & Flaherty et al., 1971 \\
\hline \multirow[t]{3}{*}{$\begin{array}{l}\text { Integration of } \\
\text { animals into the } \\
\text { farming system }\end{array}$} & $\begin{array}{l}\text { Use of geese in } \\
\text { cotton, vineyards } \\
\text { and orchards }\end{array}$ & $\begin{array}{l}\text { Control of grass } \\
\text { weeds such as } \\
\text { Johnson grass, } \\
\text { Bermuda and } \\
\text { nutgrass }\end{array}$ & $\begin{array}{l}\text { Conley and Peterson, } \\
1957\end{array}$ \\
\hline & $\begin{array}{l}\text { Chicken manure in } \\
\text { alfalfa }\end{array}$ & $\begin{array}{l}\text { Higher yield than } \\
\text { alfalfa treated with } \\
\text { superphosphate }\end{array}$ & May and Martin, 1966 \\
\hline & $\begin{array}{l}\text { Dairy manure in } \\
\text { citrus and avocado } \\
\text { orchards }\end{array}$ & $\begin{array}{l}\text { Efficient source of } N \text {, } \\
P \text { and } K\end{array}$ & Embleton and Jones, 1956 \\
\hline
\end{tabular}


gies and their ecological effects

\begin{tabular}{|c|c|c|c|}
\hline $\begin{array}{l}\text { Diversification } \\
\text { strategy }\end{array}$ & Cropping system & Main effects & Reference \\
\hline \multirow[t]{6}{*}{ Multiple cropping } & $\begin{array}{l}\text { Cotton-alfalfa strip } \\
\text { cropping }\end{array}$ & $\begin{array}{l}\text { Enhanced control of } \\
\text { the Lygus bug }\end{array}$ & Stern, 1969 \\
\hline & $\begin{array}{l}\text { Broccoli- fava bean } \\
\text { or wild mustard } \\
\text { intercropping } \\
\text { Asparagus- barley } \\
\text { interplanting }\end{array}$ & $\begin{array}{l}\text { Reduced incidence } \\
\text { of cabbage aphids } \\
\text { and flea beetles } \\
\text { Reduced wind } \\
\text { erosion and } \\
\text { enhanced asparagus } \\
\text { yields }\end{array}$ & $\begin{array}{l}\text { M.A. Altieri and L.L. } \\
\text { Schmidt, unpublished } \\
\text { data, } 1989 \\
\text { Schultz et ai., } 1963\end{array}$ \\
\hline & $\begin{array}{l}\text { Cotton-sudan grass } \\
\text { or German millet } \\
\text { grown in furrows }\end{array}$ & $\begin{array}{l}\text { Increased water } \\
\text { infiltration rates } \\
\text { improving irrigation } \\
\text { efficiency }\end{array}$ & Yamada et al., 1963 \\
\hline & $\begin{array}{l}\text { Collard-bean } \\
\text { intercropping }\end{array}$ & $\begin{array}{l}\text { Reduced flea beetle } \\
\text { incidence and } \\
\text { enhanced weed } \\
\text { suppression }\end{array}$ & $\begin{array}{l}\text { Gliessman and Altieri, } \\
1982\end{array}$ \\
\hline & $\begin{array}{l}\text { Tomato- squash } \\
\text { intercropping }\end{array}$ & $\begin{array}{l}\text { Enhanced tomato } \\
\text { yields and reduced } \\
\text { aphid densities on } \\
\text { squash }\end{array}$ & $\begin{array}{l}\text { J.A. Trujillo, unpublished } \\
\text { data }\end{array}$ \\
\hline & $\begin{array}{l}\text { Oats undersown with } \\
\text { alfalfa }\end{array}$ & $\begin{array}{l}\text { Effective weed } \\
\text { control }\end{array}$ & Flint and Roberts, 1988 \\
\hline \multirow[t]{5}{*}{$\begin{array}{l}\text { Crop field border } \\
\text { diversification }\end{array}$} & $\begin{array}{l}\text { Rubus blackberries } \\
\text { surrounding } \\
\text { vineyards }\end{array}$ & $\begin{array}{l}\text { Enhanced } \\
\text { abundance, survival } \\
\text { and efficiency of } \\
\text { grape leafhopper } \\
\text { parasitoid }\end{array}$ & Doutt and Nakata, 1973 \\
\hline & $\begin{array}{l}\text { Prune trees } \\
\text { bordering vineyards }\end{array}$ & $\begin{array}{l}\text { Abundance, survival } \\
\text { and efficiency of } \\
\text { grape leafhopper } \\
\text { parasitoid }\end{array}$ & Flint and Roberts, 1988 \\
\hline & $\begin{array}{l}\text { Coyoto brush } \\
\text { surrounding } \\
\text { vineyards }\end{array}$ & $\begin{array}{l}\text { Source of natural } \\
\text { enemies of the } \\
\text { orange tortrix }\end{array}$ & Kido et al., 1981 \\
\hline & $\begin{array}{l}\text { Weeds along edge of } \\
\text { alfalfa }\end{array}$ & $\begin{array}{l}\text { Increased dispersal } \\
\text { of predaceous } \\
\text { Coccinellidee }\end{array}$ & $\begin{array}{l}\text { Altieri and Letourneau, } \\
1982\end{array}$ \\
\hline & $\begin{array}{l}\text { Borders of wild } \\
\text { mustards around } \\
\text { cole crops }\end{array}$ & $\begin{array}{l}\text { Trap cropping of flea } \\
\text { beetles and cabbage } \\
\text { aphids }\end{array}$ & $\begin{array}{l}\text { Altieri and Schmidt, } \\
\text { 1986b }\end{array}$ \\
\hline
\end{tabular}

tal degradation, economic growth or stagnation, political change, etc. Farmers adapt to some of these changes, responding through technological innovation to variations in the physical environment, prices of inputs, etc. A logical outcome to present constraints is the desire for more sustainable agricultural methods. 


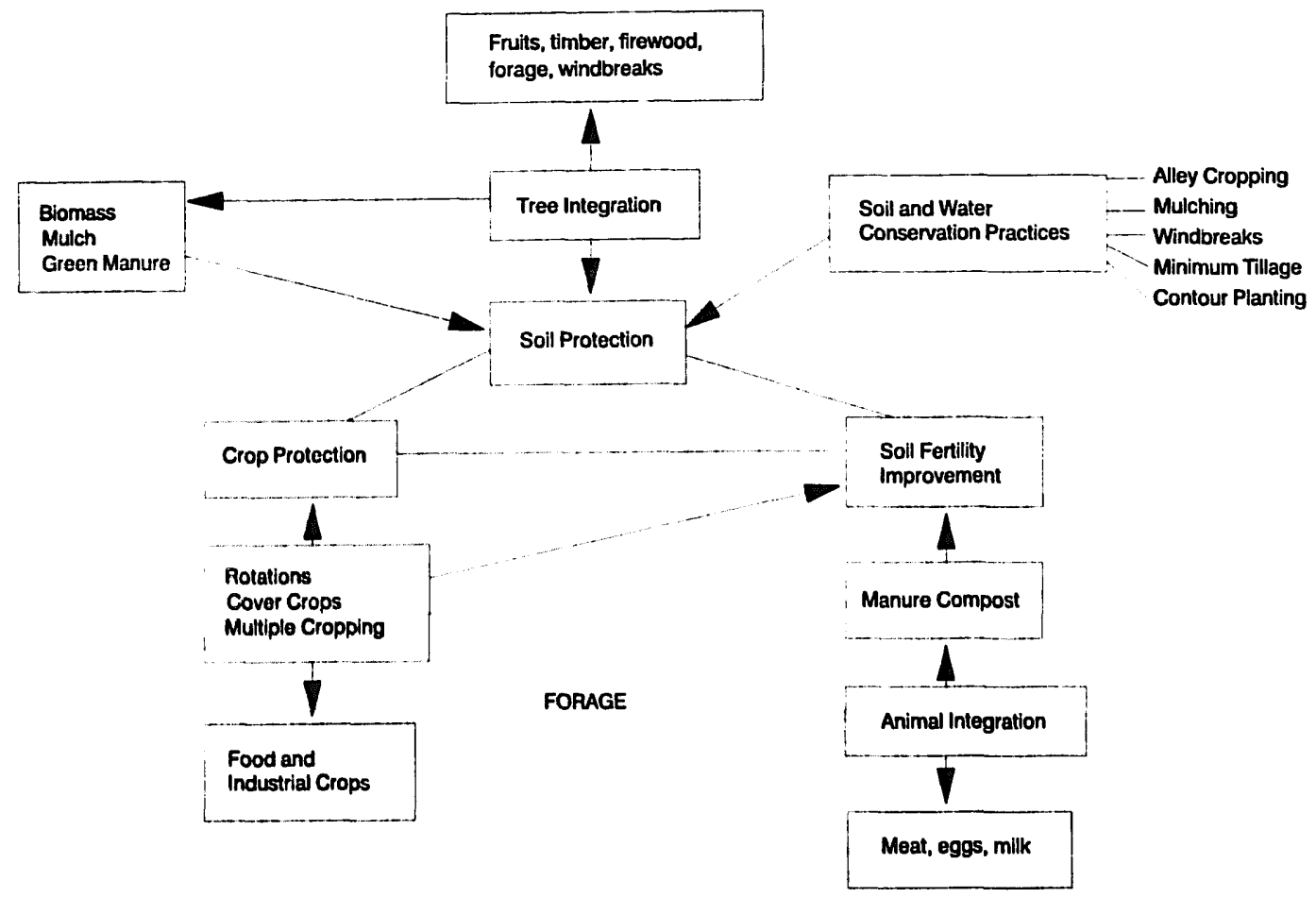

Fig. 4. Complementary interactions in diversified cropping systems resulting in enhanced soil protection, soil fertility and biological crop protection.

The basic concepts of a self-sustaining, low-input, diversified and efficient agricultural system must be synthesized into practical alternative systems to suit the specific needs of farming communities in different agroecological regions of California. A major strategy in sustainable agriculture is to restore agricultural diversity in time and space through crop rotations, cover crops, intercropping, crop/livestock mixtures, etc. (Altieri, 1987). As seen in Fig. 3 , different options to diversify cropping systems are available depending on whether the current monoculture systems to be modified are based on annual or perennial crops. Diversification can also take place outside of the farm, e.g. in crop-field boundaries with windbreaks, shelterbelts and living fences, which can improve the habitat for wildlife and beneficial insects, provide sources of wood, organic matter, resources for pollinating bees and, in addition, modify wind speed and the microclimate (Altieri and Letourneau, 1982).

Table 1 assembles a number of examples of alternative diversification strategies tested in California, summarizing the beneficial effects on soil fertility, crop protection and crop yields. If one or more of these alternative technologies are used, the possibilities of complementing interactions between agroecosystem components are enhanced (Fig. 4), resulting in one or more of the following effects: (a) continuous vegetation cover for soil protection; (b) constant production of food, ensuring a varied diet and several marketing 
items; (c) closing of nutrient cycles and effective use of local resources; (d) soil and water conservation through mulching and wind protection; (e) enhanced biological pest control through diversification; (f) increased multiple-use capacity of the landscape; $(\mathrm{g})$ sustained crop production without the use of environmentally degrading chemical inputs.

\section{THE EFFECTS OF DIVERSITY ON INSECT POPULATIONS}

The worsening of most insect-pest problems has been associated with the expansion of crop monocultures at the expense of the natural vegetation, thereby decreasing local habitat diversity (Altieri and Letourneau, 1982; Flint and Roberts, 1988). This simplification can seriously affect the abundance and efficiency of natural enemies, which depend on habitat complexity for sources of alternate prey/hosts, pollen and nectar, shelter, and nesting and overwintering sites.

Few but significant studies have explored the relationships between vegetational diversity and pest reduction in diversified cropping systems in California. A classical example is the role of the native blackberry bush (Rubus sp.) in vineyards of the Central Valley of California in the control of an important insect pest, the grape leafhopper Erythroneura elegantula. Long considered the key pest in many grape agroecosystems, this foliage-feeding leafhopper inflicts severe damage on vines and great losses in fruit yield when present in large numbers. Insecticides have often failed to give effective control of the leafhopper or their use has aggravated other pest problems, such as spider mites. Entomologists had known that the parasitic wasp, Anagrus epos, ovipositing in the eggs of the grape leafhopper, kept the pest under control in some vineyards, but not in others.

The riddle was solved when it was realized that the wasp spent its winters parasitizing a different insect on Rubus. Since the leaves fall off grapevines in the winter and the grape leafhopper retreats to the edge of the vineyard and becomes inactive, the non-hibernating parasitic wasp has no shelter, food or means of survival in this environment. Nearby blackberry bushes, however, keep their leaves during winter and host their own economically unimportant leafhopper species, Dikrella cruentata, all year round. When entomologists checked the eggs of this blackberry leafhopper, they found corisiderable parasitism by Anagrus. Thus, the weedy blackberry patches were providing a winter home for this important natural enemy of the key grape pest (Doutt and Nakata, 1973). Accordingly, it was growers with blackberry bushes in the vicinity of their vineyards who had the least grape leafhopper problems. Anagrus adults migrating back to the vineyards in the spring kept grape leafhopper numbers at low levels from the beginning of the season. Since this discovery, many growers have solved their major leafhopper problems with the planting of blackberry bush refuges in shady areas near their vineyards. 
Recent studies have shown that prune trees planted next to vineyards allow early-season build-up of Anagrus epos. After surviving the winter on an alternate host, the prune leafhopper, Anagrus, moves into the vineyard in the spring, providing grape leafhopper control up to a month earlier than in vineyards not nea: prune tree refuges. Researchers now recommend that trees should always be planted upwind from the vineyard (but otherwise they can be managed as a typical commercial prune orchard) and to plant as many trees as is ecoromically feasible, since the more trees there are, the more productive the refuge is likely to be. Equally, research suggests that Coyote brush plants (Baccaris pilularis) adjacent to vineyards could play a similar role in the control of the orange tortrix by providing alternative food sources to parasitic wasps such as Exochus and Apanteles (Kido et al., 1981).

Researchers are also realizing the benefits of cover crops in orchards to manage pest populations. In Northern California, substantially more male coddling moths were caught in disked apple orchards (a total of 275 caught on nine sampling dates) than in cover-cropped orchards (164 moths) containing bell beans, vetch and natural vegetation. Densities of the rosy apple aphid (Anuraphis roseus) were slightly higher during May and June 1982 in the disked than in the cover-cropped orchard. In 1983, rosy apple aphids were detected only in the disked orchard, where they reached high numbers in early June. Leafhoppers (Homoptera: Cicadellidae) colonized the orchards late in the 1982 season, reaching substantially higher densities in the disked than in the cover-cropped orchard (Altieri and Schmidt, 1986c).

In Central Valley vineyards, variegated leafhopper population differences between cover and non-cover plots were clear cut for all three broods, but the reasuns behind these differences were not so clear. Anecdotal reports from growers in the area suggest that weedy cover crops in early to mid-season may have smaller populations of leafhoppers. An increase in the abundance of generalist predators, especially spiders, may help reduce leafhopper populations in the weed-cover plots (Settle et al., 1986). In the same area, leaving a managed ground cover of Johnson or Sudan grass, a minor cultural practice modification in vineyards, resulted in a habitat modification which has greatly enhanced the activity of predators against phytophagous mites such as the Williamette mite.

Also in the San Joaquin Valley, the emergence of navel orangeworm adults (Amyeolis transitella) was significantly higher in the complete, residual herbicide-treated almond orchard than in orchards with a vegetation cover. These results show that fewer navel orangeworms survive the winter on the ground where cover crops are present. The differences might be greater where nuts in cover crops are fully subjected to regular, early-spring mowing. Nuts in the residual herbicide treatments, which do not need mowing, would not be disturbed. Mowing, especially flail mowing, could reduce the navel orangeworm population further by physically destroying the overwintering nuts and larvae. 
The beneficial effects of diversification are also evident in annual cropping systems. Strip-cropping, a form of intercropping characterized by two or more alternate rows of crops, is common in the USA (i.e. corn/soybean strip cropping). In California, cotton-alfalfa strip cropping has been tested for Lygus bug control with encouraging results. The effect of this system is that the alfalfa strips act as a trap crop when the invading Lygus colonize the cotton fields. Also, the strips serve as an insectary for natural enemies of other cotton pests. The natural enemies leave the alfalfa strip and enter the adjacent cotton to attack eggs and small larvae of the bollworm, cabbage looper and beet armyworm (Stern, 1969).

In the coastal areas of Northern California, populations of cabbage aphids (Brevicoryne brassicae) and flea beetles (Phyllofreta cruciferae) can be significally reduced in broccoli when this crop is grown interrupted with fava beans, wild mustard, vetch, barley or with living mulches of various clover species (Gliessman and Altieri, 1982).

\section{THE BUILDING BLOCKS OF SUSTAINABLE AGRICULTURE IN CALIFORNIA}

\section{Classical biological control}

Since most crops in California are introduced from abroad, they are subjected to attack by exotic pests that lack natural enemies in the new environment. This fact was quickly realized by the California citrus farmers early in the century when the introduction of scale insects threatened the industry. Classical biological control gained much local and state government support to deal with pesis such as the cottony-cushion scale, klamath weed and others. In fact, it is estimated that the combined savings attributed to seven major projects of classical biological control are approximately $\$ 250$ million. These figures do not take into account the reduction in environmental costs that otherwise would have occurred with the use of pesticides. The long tradition in biological control in California has served as a major building block for the emergence of the organic agriculture movement in the state because it has set the precedent of the potential for farming without the use of insecticides. The following is a brief description of four major and successful attempts (DeBach, 1964; Huffaker and Messenger, 1976) at biological control.

\section{The walnut aphid}

Chromaphis juglandicola has been a serious pest of walnut in California since the early part of the century. Thousands of acres of walnut were routinely treated with chemical insecticides to control this pest. Initially, nicotine sulfate was the most widely used material; however, since the mid-1940s it has been supplanted by a variety of synthetic organochlorines and organo- 
phosphates. Chemical control of the aphid is costly, disturbs the walnut ecosystem, causes rapid resurgence of the pest, can create 'secondary pest' problems and is hazardous to warm-blooded animals, honeybees and other pollinators. Furthermore, the aphid had developed resistance to a succession of insecticides used against it.

In 1959, a parasitic wasp (Trioxys pallidus) was successfully imported into California from Southern France and became eminently effective against the aphid in the coastal plain of Southern California, spreading rapidly and destroying a very high percentage of the host population. However, this parasite was not well adapted to conditions in Northern and especially Central California where, in spite of large-scale releases, it apparently never became permanently established. Another strain of $T$. pallidus was obtained from: Iran in the late spring of 1958 and colonized in several areas of Central California during the summer and autumn of that year. Results were prompt and spectacular. Surveys conducted in the spring and early summer of 1970 showed that the parasite was having a heavy impact on $C$. juglandicola at a number of places. By the end of that year, it had virtually covered all of the walnutgrowing areas of Central and Northern California, an area of perhaps 50000 square miles. By the spring of $1971, T$. pallidus had a generally crushing impact on the aphid and the aphid is now virtually nonexistent in the major production areas.

\section{California red scale}

This scale, Aonidiella aurantii, became established in California by the 1870 s and for years was the primary pest of citrus, being responsible for losses of millions of dollars annually from damage to trees, loss in fruit quality and cost of insecticidal treatment. Attempts at biological control began in 1889 when the first predatory beetles were sent from Australia, and work has continued with varying degrees of emphasis up to the present.

Four species of parasites are responsible for the degree of biological control now achieved. All were established between 1941 and 1957, with the last one being the most important. Two species of Aphytis are, in general, the most effective of the natural enemies. Each of these alone can regulate California red scale populations at extremely low levels if habitat conditions are favorable to them. Aphytis melinus, imported from India and West Pakistan in 19561957 , is the most effective parasite and is completely dominant in interior areas and generally in intermediate climatic areas, but is complemented in its work by the red scale race of Comperiella bifasciata which was imported from South China in 1941. This was established from an original stock of only five mated females. Aphytis lingnanensis, imported from Southern China in 19471948 , remains generally dominant in coastal districts, but is strongly comple- 
mented by the red scale race of Prospaltella perniciosi imported from Formosa in 1949.

The degree of success in the biological control of the California red scale in California can now be considered as substantial. In groves under good biological control, the scale has been brought almost to extinction. Many thousands of acres now go untreated each year with enormous savings to the citrus industry. There are certain climatic areas where the parasites currently established are rendered ineffective by cold winter weather, hot summer weather, or both. In general, the degree of unfavorability increases with distance from the coast. Thus, in the desert areas of the Imperial Valley, the extent of biological control is greatly reduced.

The olive scale

Parlatoria oleae was the most serious pest of olive in California from soon after the time of its discovery in 1934 until after a biological control campaign was begun in 1948. During the period before biological control was accomplished, commercially acceptable crops of olives could not be produced without the use of pesticide applications.

Several importations of Aphytis maculicornis were made from several countries, but only those introduced from France colonized and became established throughout much of California. However, the degree of biological control was variable and, in some cases, not commercially adequate. The main reason for this is the harm caused to the parasite by the intensive summer heat and low humidity that occurs in the commercial olive-growing areas of California.

Nevertheless, in many olive groves very satisfactory commercial control of the scale was provided by Aphytis maculicornis. Furthermore, subsequent to the establishment of this parasite, there followed a marked general decline in the pest on essentially all of its other host plants.

In 1951-1952, another parasitic Hymenoptera, Coccophagoides utilis, was introduced from India and Pakistan. After a culture technique for Coccophagoides utilis was devised, the parasite was colonized at several locations in California during the period 1957-1958. Establishment occurred in 1961, when the parasite was recovered from two of the original release sites. It was found to occur in association with the previously established Aphytis maculicornis. Subsequent studies disclosed that rather than competing with each other to the detriment of the combined control effect, these two parasites supplemented one another. This supplementing effect was of such a nature as to result in excellent biological control of the scale. While Aphytis maculicornis was shown to be adversely affected by summer heat and low humidity, Coccophagoides utilis on the other hand manages to survive the summers without 
undue losses. Being an excellent searcher of scales, it manages to produce levels of parasitization reaching $60 \%$, even at low scale densities.

\section{The spotted alfalfa aphid}

Therioaphis trifolii arrived in California in 1954 and caused up to $\$ 10.6$ million of crop losses in 1957. An integrated pest management program was quickly implemented and in 1958 losses fell to $\$ 1.7$ million in just 1 year. Today, the pest rarely assumes injurious status.

Classical biological control was a major component of the integrated pest management (IPM) strategy. Three species of hymenopterous parasites were imported fiom the Near East and Europe, and established in California. These introduced natural enemies contributed significantly to the control of the aphid. A cultural control, strip harvesting of alfalfas, was employed. The practice of strip harvesting enhanced the action of both the introduced and naturally occurring biological control agents by providing refuges from these natural enemies. Timely irrigation was also utilized to enhance the activity of a virulent fungus that caused a disease in the aphid. A sound economic threshold for the pest was established and a sweep-net sampling method for predators was standardized. When necessary, a selective insecticide, demeton (Systox $^{\circledR}$ ), was developed that killed the spotted alfalfa aphid, but was less destructive to natural enemy populations. The need for any insecticide treatments for the spotted alfalfa aphid was eliminated, however, by the introduction of alfalfa varieties resistant to the spotted alfalfa aphid.

\section{Research on sustainable agriculture in California}

The University of California's Agriculture Research and Education Program (UC-SAREP)

The UC-SAREP Program was established in 1986 to address concerns about the economic viability of farming and the effects of current farm practices on the environment and on human health (UC-SAREP, 1988). The program has three main responsibilities: the administration of competitive research grants, the development and dissemination of new and existing scientifically based knowledge, and the coordination of long-term farmland research. Public and technical advisory committees advise the program on goals and make recommendations on the award of competitive.grants. The program funds research and distributes information on sustaining practices. Since 1987, UCSAREP has spent $\$ 1.2$ million on 51 sustainable agriculture research and education projects.

Among the 22 projects funded in 1990, research topics include (UC-SAREP, 1990) the following.

(1) A comparison of the work and labor needed in sustainable and conven- 
tional agricultural production systems. Focusing on table grapes and carrots, this project will document labor management adjustments needed during the transition to more sustainable production systems.

(2) A method for estimating the rate of inorganic nitrogen release from organic fertilizers. The objective of this project is to develop and test a practical method for predicting the rate at which nitrogen found in manures or composts is converted to usable forms for plant growth.

(3) Profiles of five sustainable farms. A survey of the short- and long-term consequences of adopting sustainable practices, including biocontrol (use of beneficial insects to control insect pests), in relation to cover crop choices, natural fertilization and integrated pest management systems on five grape and stone fruit farms.

(4) A Central Californian comparison of organic and conventional commercial almond orchards farmed side by side by two brothers. The study focuses on developing management guidelines for low-input organic or low-input sustainable almond farming practices.

(5) Biological control of aphids in lettuce using infield insectaries. This project consists of a multi-disciplinary study to improve the biological control of aphids with in-field insectaries: carefully chosen plant species planted in lettuce fields to provide food and shelter for both existing and introduced natural enemies of aphids.

(6) Comparison of two high-value perennial cropping systems (apples and artichokes) in coastal Central California during conversion to low-input farming practices. This project will document the ecological and economic trends of these crops during the transition from conventional to low-input management. Information about important limiting factors during the transition to low-input production is critical in order to lessen economic risk.

(7) Effect of rice straw incorporation and green manure cropping on rice nitrogen nutrition, stem rot incidence and soil tilth. Most Californian rice growers depend on commercial nitrogen fertilizer and dispose of rice straw by burning; fertilizer price increases, and farmer interest in soil improvement and organic rice production methods have raised questions about green manures (crops grown to be incorporated into a cash crop for soil enhancement) and straw incorporation, and the interaction of these two practices. This project will continue a 15 acre experiment to determine nitrogen nutrition and soil tilth effects of green manuring with purple vetch.

(8) The feasibility of using manure and other selected practices in organic and conventional cropping systems. The use of manure as a fertilizer for most cultivated agriculture has been avoided due to concerns that the quantities required would be huge and costly. However, there is now evidence that California has a net surplus of cow manure. The first part of this project will look at the costs and benefits of manure fertilizer. The second part will calculate 
the costs of production and economic analysis of other practices in wholefarm production systems.

Recently, UC-SAREP decided to concentrate its major funding on longterm farmland studies. A project entitled 'Long-term Research on Agricultural Systems: Crop Diversity and Input Level as Determinants of Function and Evolution of the Agroecosystem', submitted by a team of 18 researchers at the University of California at Davis, was awarded $\$ 150000$. The longterm project is located on 300 acres dedicated to long-term research on agricultural systems in Yolo County. The first experiment on the site is a 60 acre study of annual cropping systems. The project will study the long-term effects of crop management systems. The first study will focus on annual field crop systems that include rotations with wheat, corn, tomatoes and winter legume cover crops. The experiment will compare the performance of cropping systems that differ in levels of irrigation water, nitrogen rates and sources, and cropping diversity. Nitrogen sources will include fertilizer, legumes and compost. The variables in this experiment will create wide differences with respect to organic matter production, recycling and management. The monitoring of soil and environmental conditions will allow comparisons among cropping systems based on economic returns, and effects on soil and water resources in the long run.

Information from this project will be used to identify crop management systems that are both economically viable and not damaging to the environment. Crop management guidelines and strategies for all treatments will be developed by a committee that includes both conventional and organic farmers, the investigators, a farm supervisor and a staff research associate.

Although funding of this project at the expense of other research programs was highly controversial, UC-SAREP argues that this experiment relates directly to SAREP's responsibility to examine the long-term viability of Californian agriculture.

\section{Conversion of organic production to organic management}

Like many other crops in California, conventional strawberry production has confronted a series of problems. A key pest spider mite, Tetranychus urticae Koch, has developed resistance to most registered acaricides. At the same time, regulatory restrictions affecting the availability and frequency of use of chemical controls are on the increase. Growers continue to depend on soil fumigation and the application of highly soluble inorganic nutrients. Production costs continue to rise.

However, some strawberry growers have found economic and environmental incentives that encourage them to convert their high-input production systems to practices that depend less on external inputs. These include price pre- 
miums from consumers for residue-free products, fewer regulatory restrictions on farm inputs and their off-farm impacts, and lower production costs.

The interdisciplinary research team at the University of California at Santa Cruz Agroecology Program has developed a systems-level protocol for the simultaneous, comparative monitoring of yield-affecting variables in conventional and organic conversion farm production (Gliessman et al., 1990). They applied the protocol to a multi-year study of the process of conversion to lowinput farming practices for strawberries.

Working with a small-scale strawberry grower with conventional production experience, but who has also successfully begun the transition to legally certified organic production, in the fall of 1987 researchers established annual strawberry production on a 0.5 -acre plot in a randomized, complete block-design with six replicates of two treatments: (1) conventionally recognized production guidelines recommended by the University of California Cooperative Extension; (2) management without synthetically derived inputs in accordance with the California Health and Safety Code Section 26569.11-.17 and the California Certified Organic Farmers guidelines and enforcement provisions.

After the second year of comparisons, results indicated the following trends.

(1) Levels of soil organic matter at a depth of $15 \mathrm{~cm}$ were not significantly different in the two production systems.

(2) No significant differences in soil $\mathrm{pH}$ were observed between production systems.

(3) An early season determination of soil bulk density at a depth of $10 \mathrm{~cm}$ indicated no significant differences between the two systems.

(4) An early season test of soil percolation rates and water-holding capacities showed no significant differences between the two systems. No significant differences were seen in total and available soil nitrogen and phosphorus during the season, but significantly higher potassium levels were detected in the conversion system in the early ( 520 vs. 400 p.p.m.) and mid-season (486 vs. 381 p.p.m.) samples. No significant differences could be detected in cation exchange capacity.

(5) At root depth, soil temperatures in the conventional production system exceeded those in the conversion system by as much as $2^{\circ} \mathrm{C}$ through March. The clear plastic mulch used in the conventional system warmed the soil more effectively than did the black plastic used in the conversion system.

(6) Marketable fruit yield for the conversion system was $61 \%$ of that achieved in the conventionally managed plots. The earlier development of plants in the conventional production system resulted in higher fruit yields.

(7) Populations of a key strawberry pest, the two-spotted spider mite ( $\mathrm{Te}$ tranychus urticae), were significantly lower in the conventional system than in the conversion system for 7 weeks. Mean population density in the conversion system never exceeded the economic damage threshold, estimated at 20 
mites per leaflet for the winter-planted Chandler variety. Acaricides were applied three times (mid-March, early April and early May) in the conventional production systems to control the two-spotted spider mite. Populations of the predacious phytoseiid mite (Phytoseiulus persimilis), an introduced biological control agent, showed a density-dependent response to the twospotted spider mite populations from late April through May in the conversion system.

(8) A significantly higher biomass of weeds occurred in the organic plots early in the season, primarily because of the absence of methyl bromide fumigation. Six weeks after planting, the organic beds were mulched with black plastic, which successfully suppressed most weed growth.

(9) Soil fumigation and pesticide application made non-renewable input costs higher on conventional plots, although the organic production system required more hours of 25 horsepower tractor work for mechanical weeding. Labor costs were higher in the conversion system, especially for the additional weeding and picking time per unit of yield. The price differential for organic strawberries permitted a positive profit margin ( $9 \%$ less than for conventional production), despite the lower production levels.

Based on the above results, management modifications to the conversion system will be made, including the use of bed covers during the first 2 months after planting, increasing the amount of organic soil amendments and releasing predatory mites for spider mite control. Researchers are also working to establish a sound management strategy for the summer fallow period between annual strawberry plantings, in order to disrupt or control populations of harmful diseases or weeds, a goal currently achieved in conventional systems by soil fumigation. This management strategy may include cover cropping, soil solarization and soil amendments.

An important outcome of these studies is the realization that the process of converting a conventional crop production system that relies heavily on synthetic, petroleum-based inputs to a legally certifiable, low-input organic system is not merely a process of withdrawing external inputs, with no compensatory replacement or alternative management. Considerable ecological knowledge is required to direct the array of natural flows necessary to sustain yields in a low-input system.

\section{Agroecology and the resource-poor farmers in California}

Contrary to general belief, in California there are thousands of small farmers, many of them of Mexican and Asian ethnic back ground. Most of these farmers have limited access to land resources, capitai, credit and especially appropriate technology. In the Salinas Valley, there are hundreds of former farm workers of Mexican origin engaged in farming operations in an attempt at becoming economically self-sufficient. Most of them utilize high-input 
technologies, copying the practices of large-scale commercial growers for whom they have previously worked. However, the conventional methods of large-scale growers, who produce $\$ 700$ million of vegetables annually on 180000 acres, are seldom appropriate to small-scale farms. The conventional application of chemical pesticides and fertilizers, for instance, is not suited to operations with a reduced economic and resource base.

Given the above situation, researchers at the University of California, Berkeley, engaged in a cooperative research, training and demonstration project with the Rural Development Center aimed at assisting these small vegetable growers in developing and adopting low-input agricultural technologies and diversified cropping patterns (Altieri et al., 1991).

Through 1988-1990, several field experiments were performed. Several practices designed to increase energy efficiency, improve the environment and strengthen the economy of existing systems were tested.

The overall goal was to evaluate proposed innovations within the context of farmers' goals, needs and resource bases, and in terms of long-term energy savings and socioeconomic and ecological impacts. This would facilitate the adoption of low-input technologies by farmers who otherwise might perceive them as too risky.

So far, the project has demonstrated that it is possible to grow vegetables with low-input, energy-conserving technologies in an area where vegetable production traditionally involves high inputs. This can have long-term ecological, socioeconomic and public health ramifications, but such benefits will become more apparent as the conversion process from high-input to low-input agriculture continues.

As the effects of biological pest control and organic amendments become more evident, it is expected that farmers adopting the new systems will be able to reduce energy use, cut costs of production and secure diversity of production for subsistence and marketing. In fact, it is expected that the maximum yields sustained by organic methods could be much higher than those now realized. Indirect benefits may include reduced soil erosion, reduced chemical pollution, better water conservation and increased soil biological activity.

As collaborating small farmers link to speciality and natural food markets with products either certified as organic or perceived as chemical free, they will enhance their ability to obtain premium prices for their produce, thereby considerably increasing their income.

This project demonstrates the benefits of researchers and farmers working side by side to design and conduct formal trials of innovative practices, such as low-input and energy-saving systems and technologies. In this way, farmers use their own criteria for evaluating the potential benefits or risks of the proposed systems. 


\section{ORGANIC FARMING IN CALIFORNIA}

It is estimated that in California the total number of organic farmers is less than 900, occupying an area of about 30000 acres out of 7831307 acres of total harvested cropland. Today, in California, there are about 630 organic farmers that belong to the California Certified Organic Farmers. By California standards, the volume of certifiably organic food that these farmers produce is still small, less than $1 \%$ of the state's annual $\$ 17$ billion agricultural output. However, the market share is increasing - from only $\$ 15$ million in 1985 to more than $\$ 150$ million in 1990 . Predictions indicate that organic produce's market share will be $10 \%$ of the state's total output by the end of this decade (National Research Council, 1989).

Organic farmers are distributed throughout the state, with varying farm sizes (although the average farm size is about 58 acres) and levels of mechanization and management intensity. Almost every crop grown in California can be found on organic farms. Although managernent systems vary according to region, crop, and economic and environmental factors, most organic farmers tend to view their farming systems in a more holistic and assembled manner, and this perspective releases a whole new set of management and design options (Edens and Haynes, 1982). By adopting cover crops, crop rotation, interplanting, combined crop/livestock systems and general farm diversification schemes, farmers usually achieve several crop management objectives simultaneously and sometimes require little if any external supplementation in order to obtain sufficient protection for crops from pests or to achieve sustained soil fertility (Lockeretz et al., 1981).

In searching for solutions to productivity problems, organic farmers are more willing to try new crops and new crop combinations, including the use of multi-storied production systems. Planting of snow peas or beans in establishing orchards, or the use of cover crops (i.e. lana vetch, bell beans, fava beans) in mature orchards, are common systems among California's organic farmers. As indicated previously, such systems may have important implications for pest management. For example, last season in Sebastopol (Sonoma County) we found that codling moth (Cydia pomonella) infested $22 \%$ of the apples in an orchard with a cover of bell beans, whereas a nearby clean-cultivated organic orchard suffered a $45 \%$ fruit loss from this pest.

In farms where animals comprise an important part of the system, animals are used for farm labor and as sources of protein or manure, and at times as extra sources of income (i.e. sale of eggs, chicken, cheese, milk, etc.). The utilization of locally available resources for farm production purposes atiains its maximum expression in organic farms. Recycled plant debris, crop residues, animal wastes, etc., are continuously moving throughout the system.

Most organic farmers developed their management schemes without the assistance of research institutions, nevertheless their accumulated experience 
is a rich resource for the further development of alternative farming systems. The following is a brief description of specific organic farming systems in California that comprise successful examples of sustainable agricultural production (National Research Council, 1989).

\section{CASE STUDIES}

\section{Organic rice production}

The best examples of organic rice production in California are the farms of the Lundberg brothers and of the Harters near Chico.

The Lundbergs devote 100 acres to organic rice production in which a 2 year rotation that alternates rice with purple vetch (Vicia benghalensis) and fallow is practiced. Dry, unsprouted rice seed is drilled directly into the soil until the appropriate moisture is available for sprouting, at which point the field is 'flushed' (rapidly and briefly irrigated).

Following germination, and until the rice reaches a height of 2-4 in, the Lundbergs allow the soil to become rather dry. When the rice begins to show stress from a lack of moisture, the field is flushed again. After the rice plants have become fully established (3-5 in tall), the fields are kept flooded until they are drained in preparation for harvest (3-4 weeks earlier) so that the soil dries out enough to support the harvest machinery.

No crop is harvested from a field in a fallow year. Instead, purple vetch is planted in the fall following the rice harvest and again in the fall of the fallow year. The vetch normally grows rather slowly during the fall and becomes dormant during cold temperatures in winter, but by April or May it has usually produced abundant foliage that makes an excellent green manure crop or mulch. The vetch supplies about $120-130 \mathrm{lb}^{\mathrm{b}}$ of nitrogen acre ${ }^{-1}$. In the spring of the fallow year, the vetch is flail-chopped and disked under, along with the largely decomposed rice straw. The field is then laser-leveled and alternately flushed and shallow-tilled with an implement to control weeds. In some years, depending on weed populations, a fallow field may be treated with as many as three cycles of flooding and tillage.

In the spring of the year in which rice is to be planted, the leguminous foliage is flail-chopped, along with the largely decomposed rice straw, leaving a mulch on the soil. A heavy no-tillage drill is then used to plant rice seed into this mulch. The drill leaves the soil bare above the narrow rows (about 8 in apart) in which the rice seed is planted. The areas between the rice rows remain covered with the mulch, which helps control weeds.

The rationale for these management practices is based on weed and pest control, and improved soil fertility. The mulch is thought to inhibit weed seed germination and thus compensate for the disadvantage of dry seeding (the delayed emergence of the rice crop), as compared with the conventional prac- 
tice. Seeding into mulch, followed by the intermittent flooding in the early stages of rice growth and development, also breaks the life cycles of water pests, such as the seed midge, tadpole shrimp and rice water weevil, which need continuous flooding to survive.

Stemrot (Sclerotium oryzae), a major fungal disease afflicting rice in Northern California, is not a severe problem in their fields because of the methods they use to expedite the decomposition of the straw and because they subsequently incorporate it into the soil. Damage by the tadpole shrimp is prevented through intermittent irrigation during the early stages of rice growth, a process that delays the anerobic stage of irrigation (perpetual flooding) until after the rice plants have reached a height of 6-8 in. At this stage, the tadpole shrimp do not cause injury to the rice. Major weeds such as watergrass are kept under control through rotations and cultural practices.

This organic method of rice production, which is still experimental and is currently practiced by the Lundbergs, has the advantages of breaking the reproductive cycle of various weeds and other pests and pathogens, and eliminating the use of pesticides. It has the disadvantage of significantly lowering yields (44.0 cwt acre ${ }^{-1}$ ) and economic returns, even in comparison with statewide averages $\left(73.5 \mathrm{cwt}\right.$ acre $\left.{ }^{-1}\right)$ that have been adjusted for the impact of rotation (National Academy of Sciences, 1989).

The Harters utilize a similar system, but instead rely on lana woolypod vetch (Vicia dasycarpa) for the rotation (Brusko, 1984). They produce rice in only 150-200 acres each year and the remaining 500 acres of tillable soil remain planted to vetch for 2 years to build up soil organic matter. Although their yields are lower than in conventional systems, their profits average about $\$ 65$ acre $^{-1}$ more than conventional farmers due to the premium price they obtain for the organic rice.

\section{Organic grape production}

The Pavichs have two organic vineyards in California: one in Delano of 467 acres and another in Kern County of 142 acres. The Pavichs apply about 2000 tons year ${ }^{-1}$ of composted steer manure to their entire farm. This translates to about 2.5-3.0 tons acre ${ }^{-1}$ of grapes and provides approximately $94 \mathrm{lb}$ of nitrogen, $85 \mathrm{lb}$ of phosphorus $\left(\mathrm{P}_{2} \mathrm{O}_{5}\right)$ and $138 \mathrm{lb}$ of potassium $\left(\mathrm{K}_{2} \mathrm{O}\right)$ per acre. The compost is spread by small trucks driven between the rows of vines.

For trace elements, the Pavichs rely on a special preparation, an enzymedigested mixture of fish waste materials from a cannery, plus kelp, which has an analysis of 5-1-1 NPK along with calcium and micronutrients. The fish material is applied as a foliar spray at least once each year, with extra applications when the vines are stressed by pests.

For weed control, the Pavichs use no-tillage methods with a perennial rye grass (Lolium perenne) and native weed cover crop, chopped periodically. 
Hand weeding between grape vines is also used. The ground cover also supports populations of various beneficial insects that feed on pests in the vineyards.

The primary pest in their vineyards is the grape leafhopper (Erythroneura elegantula) which is often regulated by the naturally occurring parasite Anagrus. Unfortunately, this parasite is much less effective against a close relative of the grape leafhopper, the variegated leafhopper (Erythroneura variabilis), which is becoming a serious pest in fresh grapes in some parts of California.

Labor accounts for about $55 \%$ of the Pavich grape production pre-harvest costs, which total about $\$ 2.20$ per box. About $3 \%$ of their grapes are sold to health food stores, receiving a $12-25 \%$ premium price. It is evident that this grape production operation is succeeding financially.

\section{Organic apple production}

Organic apple growers in California usually grow a permanent legume or grass cover crop under the trees (Altieri et al., 1983). Each fall, many farmers plant about $100 \mathrm{lb}$ of bell beans (Vicia faba) and disk them in early spring, thus incorporating organic matter and nitrogen into the soil, improving the soil's water-holding capacity for later in the summer. Farmers also add about 2 tons of compost and 0.5 ton of limestone $\mathrm{acre}^{-1}$ year $^{-1}$. Some farmers apply a fish emulsion and/or seaweed solutions in their irrigation water at blossom time.

Mechanical disking and/or mowing are the most common methods to control weeds in organic orchards. Permanent cover crops are mowed once or twice a year for weed suppression.

The codling moth (Cydia pomonella) is the most serious insect pest affecting apples in California. Organic farmers use pheromone taps to monitor codling moth flights and male densities, and utilize botanical insecticides such as ryania or rotenone, as well as applications of summer oils, with mixed results. A number of organic farmers are using the codling moth granulosis virus (CMGV) which seems to be highly specific and innocuous to anything but the codling moth and some closely related insect species. Several problems that must be overcome, however, include the development of a sunscreen material to prevent CMGV from degrading in sunlight and practical ways to reduce the number of applications required. In a recent trial, after several applications per season, worm damage was $2-3 \%$ in Red Delicious and $1 \%$ in Granny Smiths.

A 1983 economic comparativ analysis of apple production systems revealed that the total production costs per acre for organic growers were $\$ 1200$ and their yearly fuel consumption around 10-40 $\mathrm{gal} \mathrm{acre}^{-1}$. Total production costs and fuel consumption for the conventional farmer were around $\$ 1700$ and 20 gal acre $^{-1}$, respectively. In Santa Cruz County, conventional growers 
spent $\$ 111, \$ 117$ and $\$ 122$ per acre in pesticides during 1978,1979 and 1980 , respectively. In the same years, organic growers spent $\$ 41, \$ 53$ and $\$ 91$ per acre for pest control. Based on 1981 prices supplied by chemical companies and farm consultants, a comparison was made of a model conventional apple management system with an idealized organic management system. Cost comparisons are limited to soil management operations and to insect, disease and weed control practices. All labor pre-harvest and harvest costs have been excluded because adequate data are not available. However, it is expected that such costs would be at least $30 \%$ higher in organic systems because thinning and sorting operations are more labor intensive in organic orchards (Pimentel et al., 1983). Initial analysis indicates that depending on management intensity, apple variety, age of trees, etc., a conventional apple farmer spends about \$150-200 more than an organic farmer on pest control materials and soil fertilization. However, apple production in organic orchards (average 612 tons acre $^{-1}$ ) can be as much as $25-50 \%$ lower than in conventional orchards.

Although apple yields are lower in organic systems and losses due to pests are higher (codling moth infestations can range between 6 and $60 \%$, whereas in conventional systems with stringent pesticide treatments infestation reaches a maximum of $1 \%$ ), the lower production costs may offset the above constraints (USDA, 1980). Organic farmers also usually obtain a premium price for their fresh fruits and/or juices.

\section{CONCLUSIONS}

The central issue in sustainable agriculture is not achieving maximum yield,it is long-term stabilization. Sustaining agricultural productivity in California will require more than a simple modification of traditional ad hoc techniques. The development of self-sufficient, diversified, economically viable, small-scale agroecosystems comes from novel designs of cropping and/ or livestock systems managed with technologies adapted to the local environment that are within the farmers' resources. Energy and resource conservation, environmental quality, public health and equitable socioeconomic development should be considered in making decisions on crop species, rotations, row spacing, fertilizing, pest control and harvesting. Many farmers will not shift to alternative systems unless there is a good prospect for monetary gain, brought about by either increased output or decreased production costs. Different attitudes will depend primarily on farmers' perceptions of the short-term and near-term economic benefits of sustainable agriculture.

It is crucial that scientists involved in the search for sustainable agricultural technologies be concerned about who will ultimately benefit from them. This requires recognizing that political determinants enter at the point when basic scientific questions are asked and not only at the time when technologies are 
delivered to society. Thus, what is produced, how it is produced and for whom it is produced are key questions that need to be addressed if a socially equitable agriculture is to emerge. When such questions are examined, issues of land tenure, labor, appropriate technology, public health, research policy, etc., unavoidably arise.

\section{ACKNOWLEDGMENT}

An earlier version of this paper was presented at the conference 'Organic Agriculture: a dream or an economic imperative', organized by the Soil Association of South Australia and the National Association of Sustainable Agriculture, 23-27 September 1990 at Adelaide, Australia.

\section{REFERENCES}

Allen, M.W., Hart, W.H. and Baghott, K., 1970. Crop rotation controls barley root-knot nematode at Tulalake. California Agric. (July), pp. 4-5.

Altieri, M.A., 1987. Agroecology: The Scientific Basis of Alternative Agriculture. Westview Press, Boulder, $\mathrm{CO}$.

Altieri, M.A. and Letourneau, D.K., 1982. Vegetation management and biological control in agroecosystems. Crop Prot., 1: 405-430.

Aliteri, M.A. and Schmidt, L.L., 1986a. The dynamics of colonizing arthropod communities at the interface of abandoned, organic and commercial apple orchards and adjacent woodland habitats. Agric. Ecosystems Environ., 16: 29-43.

Altieri, M.A. and Schmidt, L.L., 1986b. Population trends, distribution patterns and feeding preferences of flea beetles (Phyllotreta cruciferae Goeze) in collard wild mustard mixtures: underlying mechanisms. Crop Protection, 5(3): 170-175.

Altieri, M.A. and Schmidt, L.L., 1986c. Cover crops affect insects and spider populations in apple orchards. Calif. Agric., 40: 15-17.

Altieri, M.A., Davis, J. and Burroughs, K., 1983. Some agroecological and socioeconomic features of organic farming in California: a preliminary study. Biol. Agric. Hortic., 1: 97-107.

Altieri, M.A., Trujillo, J.A., Astier, M.A., Gersper, P.L. and Bakx, W.A., 1991. Low input technology proves viable for limited-resource farmers in Salinas Valley. Calif. Agric., 45: 20-23.

Brusko, M., 1984. A cash and cover crop. The New Farm, September/October, pp. 21-23.

Butterfield, E.J., DeVay, J.E. and Garber, R.H., 1978. The influence of several crop sequences on the incidence of Verticillium wilt of cotton and on the populations of Verticillium dahliae in field soil. Phytopathology, 68: 1217-1220.

California Crop and Livestock Reporting Service. California Field Crops Review.

Conley, C.C. and Peterson, I.L., 1957. Use of geese for grass control. California Agric. (Noveinber), p. 12.

Conway, G.R., 1985. Agroecosystem analysis. Agric. Admin., 20: 31-55.

DeBach, P., 1964. Biological Control of Insect Pests and Weeds. Reinhold, New York.

Douglass, G.K., 1984. Agricultural Sustainability in a Changing World Order. Westview Press, Boulder, $\mathrm{CO}$.

Doutt, R.L. and Nakata, J., 1973. The Rubus leafhopper and its egg parasitoid: an endemic biotic system useful in pest management. Environ. Entomol., 2: 381-386. 
Edens, T.C. and Haynes, D.L., 1982. Closed system agriculture: resource constraints, management options and design alternatives. Annu. Rev. Phytopathol., 20: 363-395.

Embleton, T.W. and Jones, W.W., 1956. Manure as a source of nitrogen. California Agric. (January), pp. 14-15.

Flaherty, D.L., Lynn, C.D., Jensen, F.L. and Hoy, M.A., 1971. The influence of environment and cultural practices on spider mite abundance in Southern San Joaquin Valley Thompson Seedless Vineyards. California Agric., 25: 7-8.

Flanders, S.E., 1949. Black scale control. California Agric., 3: 13-14.

Flint, M.L. and Roberts, P.A., 1988. Using crop diversity to manage pest problems: some California examples. Am. J. Altern. Agric., 3: 163-167.

Gliessman, S.R. and Altieri, M.A., 1982. Polyculture cropping has advantages. Calif. Agric., 36: 14-16.

Gliessman, S.R., Swezey, S.L., Allison, J., Farrell, J., Kluson, R., Rosado-May, F. and Werner, M., 1990. Strawberry production systems during conversion to organic management. Calif. Agric., 44: 4-7.

Harwood, R.R., 1979. Small Farm Development - Understanding and Improving Farming Systems in the Humid Tropics. Westview Press, Boulder, CO, $160 \mathrm{pp}$.

Huffaker, C.B. and P.S. Messenger, 1976. Theory and Practice of Biological Control. Academic Press, New York, 788 pp.

Kido, H., Flaherty, D.L., Kennett, C.E., McCalley, N.F. and Bosch, D.F., 1981. Seeking the reasons for differences in orange tortrix infestations. Calif. Agric., 35: 27-28.

Liebman, E., 1983. California Farmland: A History of Large Agricultural Landholdings. Rowman and Allanheld, New Jersey.

Lockeretz, W., Shearer, G. and Kohl, D.H., 1981. Organic farming in the corn belt. Science, 211: 540-547.

Martin, J.P. and Irvin, J.D., 1954. Crop rotation and citrus. California Agric. (June), pp. 1213.

Mazmanian, D.A., 1982. Agricultural land preservation in California: an overview. California Institute of Public Affairs, Claremont, CA, Working Paper No. 1.

National Academy of Sciences, 1989. Lost Crops of the Incas. National Academy Press, Washington, DC, 407 pp.

National Research Council, 1989. Alternative agriculture. National Academy Press, Washington, DC, $448 \mathrm{pp}$.

Parker, E.R. and Jones, W.W., 1951. Orange yields and fruit size. California Agric. (May), p. 4.

Pimentel, D., Berardi, G. and Fast, S., 1983. Energy efficiency of farming systems: organic and conventional agriculture. Agric. Ecosystems Environ., 4: 359-372.

Plucknett, D.L. and Smith, N.J.H., 1986. Sustaining agricultural yields. BioScience, 36: 40-45.

Roberts, P.A. and Thomason, I.J., 1981. Sugarbeet pest management: Nematology. Spec. Publ. 3272, UC ANR, Oakland, CA, $30 \mathrm{pp}$.

Scheuring, A.F., 1983. A Guidebook to California Agriculture. University of California Press, Berkeley, CA, 413 pp.

Schultz, H.B., Carlton, A. B. and Lory, F., 1963. Interplanting methods for wind erosion protection in San Joaquin asparagus. Calif. Agric., 17: 4-5.

Settle, W.H., Wilson, L.T., Flaherty, D.L. and English-Loeb, G.M., 1986. The variegated leafhopper, an increasing pest of grapes. Calif. Agric., 40: 30-32.

Stern, V.M., 1969. Interplanting alfalfa in cotton to control Lygus bugs and other insect pests. Proceedings of the Tall Timbers Conference on Ecological Animal Control by Habitat Management, l, Tallahassee, FL, 27-28 Feb., Tall Timbers Resear $n$ Station, pp. 55-69.

University of California Sustainable Agriculture, Research and Education Program, 1988. Sustainable Agriculture News, Vol. 1, No. 1. UC-SAREP, Davis, CA. 
University of California Sustainable Agriculture, Research and Education Program, 1990. Sustainable Agriculture News, Vol. 2, No. 3. UC-SAREP, Davis, CA.

United States Department of Agriculture, 1973. Monoculture in Agriculture: Extent, Causes, and Problems-Report of the Task Force on Spatial Heterogeneity in Agricultural Landscapes and Enterprises. U.S. Government Printing Office. Washington, DC, 64 pp.

United States Department of Agriculture, 1980. Report and recommendations on organic farming. USDA, Washington, DC.

Werenfels, L., Proebsting, E.L., Warner, R.M. and Tate, R., 1963. Covercrops improve infiltration rates. California Agric. (May), pp. 4-5.

Wilhelm, S., Evans, G., Synder, W.C., George, A., Mathre, D., Garber, R.H. and Hall, D., 1966. Cultural control of Veticillium in cotton... a three point approach. California Agric. (April), pp. 2-3.

Yamada, H., Miller, J. and Stockton, J., 1963. Dessicated grass mulch increases irrigation efficiency for cotton. California Agric. (November), pp. 12-13. 